\title{
And is there honey still for tea?*
}

\author{
SIR RONALD GIBSON
}

British Medical fournal, 1979, 1, 1185-1190

And after, ere the night is born, Do hares come out about the corn? $\mathrm{Oh}$, is the water sweet and cool, Gentle and brown, about the pool? And laughs the immortal river still Under the mill, under the mill? Say, is there Beauty yet to find? And Certainty? and Quiet kind? Deep meadows yet, for to forget

The lies, and truths, and pain ?... oh! yet Stands the Church clock at ten to three? And is there honey still for tea?

-Excerpt from The Old Vicarage, Grantchester, by Rupert Brooke (1912).

Once upon a time, in the afternoon, a very young boy was sitting on a garden wall, kicking his heels against the stones, with nothing in particular to do. Facing him was Romsey Abbey and on his left a narrow lane edged by a row of poor cottages. Outside one of these a boy, of about his age, was sitting on a box while men were moving meagre items of furniture from the house into the lane beside him. He asked his young, widowed mother what was happening and she said that she supposed that the family was being evicted. He asked what would happen to the boy. She said that he would probably be going to the workhouse. He didn't know what was meant by "being evicted" and had never before heard of a workhouse. In his small-boy fashion he soon found out the meaning of both and was scared. What was the ultimate fate of the boy to be ? Could any boy be evicted and go to a workhouse ? If so, would his mother go with him or would he be separated from her too? He went in to tea and to his warm and friendly bed, haunted by a boy who was probably going to find himself alone, without any tea and in an uncomfortable bed, surrounded by strangers.

*Based on the Winchester Address, 1979, given at New Hall, Winchester College, on 2 May 1979 by Sir Ronald Gibson, CBE, LLD, FRCS, FRCGP.

It's odd that he should think of this episode again after over half a century and perhaps even more surprising that, in remembering it, he should still feel a little cold inside. Previous Winchester Addresses have been given by eminent philosophers, sociologists, historians, economists, politicians, and clerics (to mention only a few). The small boy on the wall, who turned out to be a family doctor, cannot hope to match them in eloquence or erudition, but it might be interesting if we took a nostalgic walk through the years with these two boys to see how they, and the country in which they live, have fared. If, in so doing, we include a soupçon of philosophy, sociology, history, religion, and politics it must be elementary and plebeian in nature, from one who all his working life has inevitably been part doctor, part social worker, and part priest. I can only apologise to those who live in a more rarified, intellectual, or even monastic environment if what $I$ am about to say appears as a gross oversimplification of the facts as they see them.

\section{Class distinction}

Why, some six decades ago, was one boy sitting on a wall with nothing to do until teatime and another sitting on a box with nowhere to go but the workhouse; with the church stolidly standing there as it had for centuries, starkly awesome and apparently unconcerned with what was going on around it ? It would be my first oversimplification if I were to say that this was because the one belonged to a social class categorised as "the middle," while the other lived in a lower stratum; and that the church was a refuge of respectability on Sundays for the one and "not for the likes of" the other.

There must have been more to it than that. The fathers of both these boys, after a world war of dreadful intensity (in which $9 \%$ of all men under 45 were killed) had expected a country fit for heroes to live in. This had not stopped one from dying in it nor the other from being unemployed. If the life of the middle class suffered at all as a result of the loss of a breadwinner, this suffering-largely because it was not the done thing 
to make an exhibition of oneself-was concealed within a family and social circle which knew the unwritten rules and abided by them. The outward appearance of the family as one of adequate means had to be preserved.

No help was available from the State, yet such was the emphasis on class distinction that the boy could not go to a Board school or mix-other than superficially-with those known to be of lesser station. The widow must not work to earn a living. Poised so delicately, as they were, between the upper and the lower classes, the deeply rooted ethics of those in the middle were sacrosanct. Which is another way of saying that respectability had to be maintained. The society in which the box boy's family lived-if one can describe it as living-also had its unwritten rules but they were concerned more with keeping alive, eating when the opportunity arose, sleeping if necessary (and it nearly always was necessary) all in one room, keeping warm by being close together, and dressing in what cast-off clothes were available. The main sacrifice, again, had to be made by the wife and mother. Indeed, she started her sacrificing during her pregnancy. She was in the hands of a midwife whose activities were governed by the Midwives Act of 1903, which required her to call for medical aid only if some abnormality was discovered or a dire emergency occurred. The Chief Medical Officer of the Board of Health in 1914 said that it was to be hoped that in future careful inquiries would be made by the midwife before the confinement and the patient transferred to the "maternity centre." Inquiries, we note, and not necessarily examinations.

As a wife, her prime aim was to keep her husband as fit as possible so that he could work and bring home some moneyand to be able to keep her children clean and healthy. She wished to be recognised as a member of what was known as the "deserving poor." She could not conceal her family's poverty, yet even poverty could be made to look dignified. She was constantly aware that the line dividing employment and respectability from unemployment and a desperate struggle for existence was thin and fragile. George Orwell's description in The Road to Wigan Pier is worth repeating: "At the back of the house a young woman was kneeling on the stones, poking a stick up the leaden pipe which ran from the sink inside and which I suppose was blocked. I had time to see everything about her-her sacking apron, her clumsy clogs, her arms reddened with cold. She looked up as the train passed and I was near enough to catch her eye. She had a round, pale face, the usual exhausted look of the slum girl who is 25 and looks 40 , thanks to miscarriages and drudgery; and it wore, for the second in which I saw it, the most desolate hopeless expression that I have ever seen."

\section{Years of depression}

The poverty line defined by Seebohm Rowntree accepted an income that could provide the rent and a bare minimum of food and fuel (the diet containing no meat, vegetables, or fruit). It was a poverty line barely adequate to sustain human life. In York $15 \%$ of wage earners and in Southampton $20 \%$ were living below this line; one-quarter of all male wage earners were below the line and $11 \%$ of all children attending elementary schools in London were suffering from malnutrition. One-half of those who volunteered for service in the first world war were rejected as physically unfit. After the war there was a shortlived boom which, while providing work for our demobilised hero, also encouraged inflation. Wages were, admittedly, $170 \%$ higher than in 1914, but wholesale prices were $207 \%$ above prewar level. Employers found that the best way to lower costs was to reduce wages. From here it was not difficult to cross the line to unemployment-and this not the temporary unemployment of Victoria's days, but a new and permanent type. There just was no work.

Trade unions in these days were aiming essentially at a partnership with employers. They showed restraint and responsibility and they did not seek conflict. The country had to accept the possibility that a body of unemployed would become a permanent feature of society. Since the box boy's unemployed father had been earning less than $£ 250$ a year and had genuinely tried to find work, he had received $75 \mathrm{p}$ a week for 15 weeks. After this, his only resort was to poor-law relief. His unemployment was made just bearable by two periods of 16 weeks each, when the government-not prepared to take the responsibility of providing employment for him-allowed him $25 \mathrm{p}$ a week for his wife and $5 \mathrm{p}$ for each child-the national dole. On the whole, he was not mutinous. He regarded with grim good humour the fact that society considered he had no one but himself to blame for his enforced idleness and that he was being treated generously. After this, unprotected by anyone, the only hope for the continued existence of the family was the workhouse. It had required no fire nor flood to rob the family of all they possessed. Unemployment and near starvation were enough. The workhouse was the place fit for this hero to live in. The workhouse was designed to offer a lower level of life to that which any work outside could provide.

So, the voyeur on the wall watched without understanding, and was frightened. The world in which he lived and that part of it which immediately surrounded him had, up to that time, been pretty good. The people he met in the shops on weekdays and in the Abbey on Sundays seemed happy and apparently prosperous. And this was so. The general level of living standards was rising. Health was improving. More houses were being built (but not enough to get rid of the slums). Mr Baldwin was trying to reduce unemployment by imposing a tariff on imported goods; after him Ramsay Macdonald increased the rates of unemployment benefit and abolished the interval between periods on the dole. Strike had followed strike, but when the General Strike came it was regarded as a challenge to Parliament. The TUC was unhappy. Trade union leadership was distrustful of its left wing and feared possible revolution. It confined itself, therefore, to little more than speeches of regret. Union leaders could not so easily make themselves national figures in those days. After the strike collapsed the condition of the unemployed worsened, with wholesale deprivation of benefits on the grounds that applicants were not genuinely seeking work. Yet there was no work to seek. Suffering and humiliation were immeasurable.

Despite this, as our wall boy proceeded to boarding school and to be even more sheltered from the world of reality, the jazz age was arriving. The rich were said to be less rich and the poor less poor. Wireless was appearing in the homes and earphones in school dormitories. Music halls were giving place to cinemas and the country seemed reasonably stable and happy. The box boy had done well at his school, which he was now preparing to leave at the age of 14 ; his father, too, was working again and feeling more secure. But as the 1930s arrived another crisis was looming. Exports dropped from $£ 729 \mathrm{~m}$ to $£ 391 \mathrm{~m}$ a year. Unemployment rose from $2.5 \mathrm{~m}$ in 1930 to $3 \mathrm{~m}$ in 1933. What followed we can guess. The government introduced measures that included a reduction in unemployment benefit. Ten per cent of the population was suffering from malnutrition and $62 \%$ of all recruits to the Army in 1935 failed to reach the necessary standards-rather more than at the beginning of the first world war.

An unemployed man after 26 weeks of benefit, which he drew as his right, had to go on the dole. This entailed a means test and everything was counted against the dole, including war-widows benefits, old-age pensions, and Post Office savings. Officials could enter the house to assess the value of furniture; neighbours could report that a child had new shoes. Perhaps there was so little reaction to all this because the poor were now living in an environment of indoor sanitation, electric light, gas cookers, bus services to work, smaller families, and real wages slowly rising. Despite the rush on Sterling and leaving the gold standard, London remained the principal money market of the world and at the next general election extremes of political opinion were ignored. 


\section{New prosperity}

This time the emergence from depression was due to a worldwide recovery in trade. Unemployment fell to $1.5 \mathrm{~m}$ in 1937 , the cuts in unemployment benefit were restored in 1934, salaries returned to their former levels in 1935, and income tax was reduced from $5 \mathrm{~s}$ to $4 \mathrm{~s} 6 \mathrm{~d}$. Yet undoubtedly the most important thing to note is that exports were half what they had been in 1914.

We are right to guess that another boom followed. With an increasing number of private houses being built, the sale of furniture rose. Those selling consumer goods depended on electric power. Up went employment in a wide variety of electrical engineering. The car and the aircraft industries both thrived, so helping steel production (there were 500000 cars manufactured in 1937, as opposed to 95000 in 1923). Chemical industries and textiles were also on the up and up and one house in three was wired for electricity as opposed to one house in 17 in 1920. One wonders whether the 1930s, with mains radios, vacuum cleaners, cookers, gramophones, and electric irons, were so austere as they have been depicted. Perhaps the answer is that, against this new level of prosperity for many sections of the working class, we have the paradox of unemployed misery. J B Priestly, in 1934, described the country as the England of: "Arterial and by-pass roads, filling stations and factories that look like exhibition buildings, giant cinemas, dance halls and cafés, bungalows with tiny garages, cocktail bars, Woolworths, motor coaches, wireless, hiking, factory girls looking like actresses, greyhound racing and dirt tracks, swimming pools, and everything given away for cigarette coupons."

Our two heroes fared well. The one, deciding to be a doctor, entered the university and medical school of his first choice with little difficulty and qualified in a profession that would provide him with a secure career and a reasonably adequate income for life. The other, leaving school at 14, went into light engineering, even though this meant moving away from his home town and thus displaying a mobility to which the British working man is usually averse. He had started at the bottom and was already several steps up the ladder when the boom came. The family now had their own council house.

As Britain approached 1939 it depended on the rest of the world. In 1746 it could be cut off from the world without disaster; in 1939 to be cut off for even a short time would have meant starvation. Only one-third of the total food supply was produced at home and Britain depended on overseas markets for coal, manufactured goods, raw materials, and foodstuffs. It was said that Napoleon's nation of shopkeepers had been replaced by shop assistants, clerks, waiters, and machine attendants. While in some other countries, such as Japan, markets were strongly organised and protected by the State, machinery modernised, and selling systems highly efficient, in Britain many industries apparently preferred to resort to policies of restricted output and higher prices instead of ensuring lower costs of production and, therefore, higher sales; no efficient organisation for the sale of exports was devised and economic and political policy were relatively slack.

\section{Moral and economic revolution}

Our two young men joined the armed Forces. Their hope was that they would return to a country which this time would really be fit for heroes to live in. From the point of view of our story, the war highlighted one aspect of civilian life-brought it out of the shadows, so to speak-to which I must refer, because it was to have a definite bearing on the life of both men on their return to civilian life six years later. Between 1939 and 1941 some three million of the poorer classes were evacuated from dangerous areas to other, safer, parts of the country. Thus they were clearly seen in their poverty by the nation at large. Brought out of their hiding places, they could no longer be ignored. Many evacuees, suffering from long-term poor feeding and hygiene, showed signs of disease and physical debility to the extent that in some cases they had difficulty in coping with a properly balanced diet. They were ill-clothed and ill-shod. This was more than the conscience of a so-called civilised country could stomach. The problem of social justice, it was decided, had to be tackled at its roots and plans were prepared accordingly. Lord Woolton truly said that there had been "a moral as well as an economic revolution in our society."

So it was that social services, which had been developing since 1900 in a piecemeal and patchy fashion-designed to meet the needs of different sections of the population as they appeared, with the administrative chaos associated with incomplete and inadequately considered legislation-were to be replaced after the second world war by a comprehensive system of services, brought together in a report by Lord Beveridge in 1944. Lord Beveridge, the 100th anniversary of whose birth we celebrate this year (and who gave the Winchester Address in 1955) recommended a constructive policy of full employment. In reply, the Government accepted the responsibility not for maintaining full employment but for a "high and stable level of employment," which is another way of saying something quite different.

I want to pick out one or two of the comments in this report, for they are particularly important and we shall need to return to them at the end of our story. Firstly, it is the duty of the State to provide for all a minimum income and standard of health, education, and housing; secondly, the aim of the plan for social security is to abolish want by ensuring that every citizen willing to serve within his powers has at all times an income sufficient to meet his responsibilities; thirdly, want is only one of the five giants on the road of reconstruction and in some ways the easiest to attack; fourthly, social security must be achieved by co-operation between the State and the individual. And finally: the State, in organising security, should not stifle incentive, opportunity, and responsibility; in establishing a national minimum it should leave room and encouragement for voluntary action by each individual to provide more than a minimum for himself and his family.

Nothing in Beveridge therefore suggested that the State should take over the be-all and end-all of the individual struggle for existence or swallow up each of us in a dull and dreary tapestry of personal irresponsibility within a framework of State paternalism. There can be little but praise for the establishment of a welfare state on the appointed day in July 1948, embodying the National Health Service, the National Insurance, and National Assistance Acts, and added to the Family Allowance Act which had been in existence since 1945. All this was achieved by a government faced with a serious economic dilemma; in fact, the Economic Survey of 1947 said that "the task of directing by democratic methods an economic system as large and complex as ours is far beyond the power of any Government."

The postwar Socialist Government pursued a policy designed to narrow the income gap between the standard of living of the working class and that of the rest of the population-a section that Aneurin Bevan described as "lower than vermin." Food subsidies and low rents kept wage demands down and unemployment was less than $2 \%$. In education, the 11 -plus became a competition for the limited number of grammar-school places and the whole course of a lifetime could be settled at the age of 11 when deciding whether to end schooling at 15 or to take the road to higher academic qualifications. This would have been helpful to our box boy, but was denied him. His son, however, was taking full advantage of it.

\section{Affluence and unrest}

The next Conservative Government changed very little of the Socialist legislation. Each year 300000 houses were being built; agriculture was heavily subsidised, giving farmers a guaranteed price for their produce; by the mid-'50s the prewar figure of 
children staying at school until 17 was doubled; by the mid'60s 345 miles of motorway had been built; and localgovernment expenditure, which had been $15 \%$ of the Gross National Product at the beginning of the century, was $40 \%$ by 1960. Thus the whole apparatus of government was expanding, by 1964 to include half a million civil servants, and fears that the rights of the individual were being swallowed up in a vast, anonymous machine were justifiable; officialdom was becoming more widespread and increasingly irritating.

Yet affluence, or the appearance of affluence, was the order of the day, with washing machines, record-players, and television, $9.5 \mathrm{~m}$ cars on the road by 1967 , and, thanks to wage increases and expanding credit facilities, package tours taking millions of people on holiday each year. The Government spent $£ 295 \mathrm{~m}$ on scientific research in 1965 compared with $£ 6.6 \mathrm{~m}$ in 1945 . The production of steel was doubled; output of cotton was increased; cars, oil-refining, and chemicals were the most rapidly growing industries. Advances in science and technology were by now not just exciting and hopeful but both thrilling and terrifying. Yet once more we must underline that by 1960 most countries inside Europe were far outstripping Britain in the growth of output in major industries because, as we know, they had invested more in new equipment in the 1950s.

Nor was increasing prosperity producing peace, quiet, and conformity; an atmosphere of restlessness prevailed, a searching around for new excitements. Young people were revolting against the establishment in an effort to build a bright new world. The social classes were mixing together as never before. In the '50s came the Teddy Boys and an increase in youthful crime and violence; in the ' 60 s came the Beatles, long hair, and all classes sharing everything, except perhaps the same accent. This was the decade of new-found freedom, high wages, and greater leisure, and it was followed, as we might guess, by the inevitable inflation and then a pay pause.

Christopher Booker in The Neophiliacs, which I found fascinating reading, sums it up in these words: "The element of black frenzy which had characterised the years up to 1963, the desperate attempts of the nuclear disarmers, the satirists, the playrights, the 'what's wrong with Britain' journalists, to force themselves into reality on a tide of sensation, had given way to a kind of fairy world where nothing seemed to matter any longer. The frenzy was still there, as we have seen from the pop world. But whereas the 'explosion into reality' of that former age-the Labour Party Conference in 1960, the mass arrest of the Committee of 100, the Profumo affair, even the Orpington by-election-had been shattering and potent, like the surfacing of a poisonous boil-now, in 1964 they seemed simply like the popping of harmless, brightly coloured bubbles." He goes on to say that the constant search for novelty and sensation had consumed everything but itself.

The Wilson Government cut the spending on prestige products, such as Concorde, and $2 \frac{1}{2} \mathrm{p}$ was added to the cost of petrol. Two new taxes were promised, on capital gains and corporation profits, and a further promise of the first increase in income tax since the last Labour Government. The pound was falling, the bank rate was $7 \%$, hire purchase was restricted, and mortgage rates were raised. The Dunkirk spirit was invoked to pull Britain through-but such a spirit is ineffective when a country is fighting itself with two subcountries within it at odds with each other. The attempts to transform our old Britain into a new one had certain other distinctions: convictions for drunkenness had risen by three-fifths; the illegitimate birth rate had almost doubled; admissions to mental hospitals were up by well over a third; dependence on heroin and cocaine had risen by 10 times and those for less harmful drugs by an almost incalculable figure; crime rate for the first time topped a million indictable offences; and there was a $17 \%$ increase in violent crime. Teenage vandalism was spreading like a rash and gang warfare was rife.

Nigel Lawson, the new editor of the Spectator, said: "The time has come to call a halt to the restless belief that change itself is the only ultimate good and to seek instead a period of social and intellectual stability during which we can again put down roots and gather strength. But where are we to find the soil ?"

\section{Awkward transition}

Since then, successive governments have treated the country to a torrent of new legislation, entailing in almost every case new and greater expenditure, more and more administrators, and less and less efficiency. Three examples of this are the reorganisation of the Health Service, the division of Health from Welfare, and the remodelling of local government. As well as the electronic revolution, the laws on homosexuality and abortion were revised and topics such as euthanasia and legalising cannabis became controversial. The "pill" and common-law marriages became acceptable ingredients of everyday drawing-room conversation and it was said that as promiscuity moved up the social scale, contraceptives spread down it. This transition from an old England to a new one was a bit much for our two "boys" to swallow in such a short time. They were getting on in years by now. Both had resisted the temptation to emigrate. Each had a family and grandchildren. One son of the box boy, who had thought himself settled for life in his job, found his company (dealing in household goods) bankrupt in the 1966 crisis. He was unemployed for 12 weeks-twice as long as he would have been a decade ago.

The younger members of both families had been caught up in the violent social upheaval in which their generation was so deeply implicated-one or two of them in their appearance and behaviour being hardly recognisable as human beings. At the other end of the scale the box boy's family was again linked with the workhouse, but by now it had been revamped and renamed a "hospital for the elderly and chronic sick," so that a senior relative could be admitted to it with every hope of ensuring comfort and security for the remainder of life's span. It was no longer to be dreaded as a place of degradation. Similarly, eviction had become respectable, carrying with it a guarantee of alternative accommodation provided by the local housing authority.

\section{Incomplete success}

Yet, as has been said, although we have every reason to be proud of the conception of a Welfare State and of the benefits and advantages it has so far achieved, we must inevitably ask ourselves what had happened to the crusade designed to create a new England. It had started with such good intentions. Why have we not yet eliminated those five giants of want, disease, ignorance, squalor, and idleness? Why have we not achieved and maintained a "high and stable level of employment" ? Why was Lord Beveridge too optimistic when he thought that the country was ready, after two world wars and all the changes and chances of the past decades, to accept his theories and put them into practice? The complete answer to these questions cannot be given in a Winchester Address. Yet, as a family doctor and, thus, deeply concerned in the Welfare State and able, as it were, to watch it going by from my consulting-room window, I can hazard two fundamental reasons for our incomplete success so far. Reasons which, until they are fully recognised and accepted, must stop dead any hopes we have of ultimate success against the giants; and which, because they were not written in the original Act, damned the complete achievement of its objectives from the start.

The first reason may be that in attempting to free man's body from hunger, poverty, and disease the creators of the Welfare State overlooked the indisputable facts that in order to be a worthwhile man at all some degree of personal struggle for existence and some avenues by means of which an individual can strive alone to make something of himself or herself are necessary. Without a challenge welfare becomes synonymous with irresponsibility. The second may be that the creators of 
the Welfare State, in taking over the body of the nation, overlooked its soul.

\section{Freedom and responsibility}

To deal first with responsibility: Mr Heath, in his Winchester Address of 1976, quoted from words said to him on one of his visits to Peking by Mao Tse-tung: "There is one great difference between our people in China and yours in Western Europe. Ours are still prepared to struggle to reach their objective-yours are not." I do not intend to be unfair in singling out one section of society, but in this context one cannot fail to make reference to the Trade Union movement which, we know, originally sought co-operation rather than conflict. Sixty years ago we read of ominous words spoken by $\mathrm{J} \mathrm{H}$ Thomas: "The unfortunate tendency was to assume that the State could be held to ransom at any time. By this means an objective could be achieved, but if done at the expense of the State all claims to citizenship would be destroyed." Since then the State has been treated to what I have heard described as a "sickening charade." Demand upon demand by union after union.

Again, we know that in 1926 the TUC was unhappy and Trade Union leadership distrustful of its left wing. In 1979 the TUC is still unhappy and, in addition, it seems, increasingly impotent. Leaders, despite their annual television appearances, are bowing more and more to shop-floor power and are even turning to rivalry and conflict within their own movement. Twinned with wage demands has been an equally sickening rate of inflation, described by Rudolf Klein as "one of the most powerful instruments of income distribution yet invented, discriminating in favour of those who have the skill and knowhow to protect their money, as against those who do not, and undermining the traditional values which implicitly underly most social policies." And with these continuing wage demands and inflation, the country has had to live with an unacceptable level of unemployment.

These three new giants-wage demands, inflation, and unemployment-have created a new type of poverty within the Welfare State: a poverty of pride. Responsible members of Trade Unions (and they are in the great majority) must surely accept by now that, no matter against whom their actions are reputed to be directed, any victory they may gain is inevitably at the expense of the underdog, the underprivileged, the lonely, the elderly, and the sick-the very elements Trade Unionism professes to wish to protect. To deny this would be sheer hypocrisy. In short, Trade Unions, whose basic objectives have been achieved, should now be leading the nation from the bitterness of the past into the hopes and possibilities of the future. Yet we are still waiting to see the emergence of positive and constructive national leadership without which the country cannot fully honour its debt to Beveridge.

Further than this, we now have to live with a fourth giant which threatens the very existence of the nation: the strike disease, which I have named meticulitis. It is an endemic disease that reaches epidemic proportions each year and is highly infectious and inflammatory in its nature. Its incubation period is shortening each year and its prodromal symptoms becoming less recognisable. We could, if we had time, clearly define its cause; we know its signs and symptoms. What we have not achieved is a breakthrough in research on how to treat it. Clearly, mass inoculation with soothing words and peaceful phrases has proved to be worthless. We require an antibiotic to kill this disease, which will contain the will and determination of the people led by an equally determined legislature. The sooner it is manufactured the better, for-let us make no mistake -this is a vicious disease that is weakening the morale and undermining the morality of all sections of society in Britain. Its side effects corrode the standards upon which our democracy is built and with each attack its after effects leave us weakened and wide open to secondary infection by other, even more deadly elements.
Meticulitis is a disease which now warrants inclusion in every textbook of medicine and particularly, perhaps, of psychiatry. Yet not just Trade Unions, but Government and Management are implicated. No politician so far (it seems to me as a family doctor) has been prepared to grasp the nettle, preferring rather to obtain results by trying to please all the people all the time and, particularly in recent years, to hand over authority to the increasing army of what I believe are known as executives. And, as we have been told, and as seems obvious, even from the doctor's consulting room, management is not always so efficient, effective, diplomatic, or communicative as it might be. The fairest criticism of governments is that over these past decades they have tried to do too much. I wonder whether the same could be said of management.

All three must take their share of the blame for a growth of output over the past two decades at half the rate (or less) than that of most other countries in the EEC; for a national income per head which, from being higher than others in the EEC in 1967, is now low enough to make us one of the poorest European nations; for us to be alone among the major industrial countries in experiencing a substantial drop in export share and for an equally disturbing loss of competitive edge on the import side. All this from a nation that could lead the world if it really tried but which has, to date, ignored the advice of Beveridge when he emphasised that social security could be achieved only by cooperation between the State and the individual, and that incentive, opportunity, responsibility, and voluntary action must not be stifled. And there, surely, is the rub.

\section{Neglecting the soul}

Which brings me, finally, to the second mistake made by the creators of the Welfare State: that in taking over the body of the nation they overlooked its soul. The result of this has been that the insecurity bred by all these thrilling, terrifying, and worrying changes I have been describing has been left with little protection or support. Tranquillisers, sedatives, hypnotics, and soothing words have failed to appease this insecurity, as have overworked doctors and social workers. It has been assumed that if man can walk on the moon and send crafts into outer space to explore the planets and develop the hydrogen bomb and invent supersonic aircraft, the need to cater for his spiritual, supersensory, and other-wordly side ceases to be relevant. The existence of a supreme being has been proved to belong to the pages of the fairy tale and the fable.

I submit that this assumption is entirely false. It has added to rather than subtracted from man's insecurity and robbed him of a strong and unyielding mooring on which to anchor his security. Technology may have reshaped society but not the man within it. It has tried and failed to prove that there is nothing required to bind man to his true purpose but a continuing search after his own material welfare. To quote Booker again, "Man cannot be at one with himself if he is not in harmony with the entire unity outside himself ... everything he does, every pattern he makes in his life, can contribute to that unity." Society, over the past decades, has mocked the old and tried certainties that are rooted in the supreme reality of existence and attempted to transfer its faith to science, the explanation for everything which explains nothing. I cannot now develop this theme, vitally important though it is, but Ronald Knox helps us a lot when he says, "We have to accustom men's minds to the notion that it does not matter what the politicians do, does not matter even if our bishops seem to betray us, we belong to a spiritual kingdom complete in itself, owing nothing to worldly alliances."

\section{Illogical optimism}

So let us take our last look at the two elderly men who were boys when we first met them. Strangely, they are not doom-laden 
or despondent. They share with us the illogicalness of their optimism when, against all the closely analysed evidence to the contrary, they still believe in the continuing greatness of their country.

They argue that the whole history of these islands is characterised by illogicalness-it is implanted in the genes of the people. How else could the British have prevailed in two world wars or even, against all odds, humiliated Napoleon. Nor is this the first time that collective solidarity has been threatened by a decreasing respect for common values and an intrusion into established fundamental rights. They accept the dangers of illogical reasoning and the necessity of tempering it with caution and vigilance. Nevertheless, they feel it in their bones (indeed, in their hearts) that the good faith of the British people remains absolute-and it was Gladstone who said that "the British constitution presumes the good faith of those who work in it."

It would be a bit risky for them to sit on the wall at their age, but they can lean against it and talk together as friends, understanding each other's point of view. The house behind them is now converted into flats and the tennis lawn into a kitchen garden. This they accept as a symbol of the sacrifice made by a middle-class family to the Welfare State. On their left the hovels have been replaced by newly built, semi-detached, owner-occupied houses, with gardens, indoor sanitation, hot and cold water, electricity, and all other mod cons. This they know to symbolise all that is best in the new Britain that they have helped to create. They are glad to see the Abbey still standing there, apparently unchanged. They recognise it not as a monument but as a living symbol of man's need for spiritual comfort and support. Over the past decades it has been belittled, insulted, and undermined but has stood the test of this century as it has the past. To the Abbey there is nothing new under the sun.

One of the box boy's grandsons-the longest haired and mutinous of his generation-has now taken Holy Orders. His church is a room in one of the houses of a new estate. He is established and accepted as one of the family within the community, the one to whom everyone is free to go to satisfy their spiritual needs and the one who is seen to be ready to join the family doctor in giving help and advice to those who are frustrated or in trouble. He and those like him are securing the foundations of the Abbey more soundly than ever, for he is taking the church to the people.

\section{Land of hope}

And what of the nation of which these two men are a part? Despite its imperfections, they wouldn't live anywhere else. In a world in which violence, instability, and dictatorship appear to predominate men still come here for justice and to be free, while others, less fortunate, look to Britain from within their State prisons, with longing. It is thus, still a land of hope. And there is glory, too. Because despite decades of social and political upheaval, the State still remains defended and protected by the silent majority of the British people. Their traditional concept of freedom-fought for and built up over the centuriesdemands this of them. They are responsible people, willing to serve within their power and to co-operate individually with the State. Their initiative and enterprise has been stifled by governments, inflation, lack of incentive, and meticulosis, yet they remain Beveridgites whose untapped resources are ready and waiting to be utilised. You can see them on the television enjoying Sunday Half Hour or the last night of the Promenade Concerts; visiting the public library or dozing in deck chairs on the summer sands.

So our two old boys are content that there is honey still for tea-for both of them and their families. Richer honey, more evenly and more thickly spread. Honey, which one of them never dreamed, half a century ago, that he would ever taste. Who are we to do anything but wish that they may live happily ever after?

I acknowledge with much gratitude the considerable help given to me in preparing this address by Mrs I M Roseveare, librarian, the Athenaeum; Mr F M Sutherland, librarian, the Nuffield Library of the BMA; Mr E Dine, Winchester District librarian; and Mrs C Dobson, librarian, the Postgraduate Medical Centre, the Royal Hants County Hospital, Winchester.

\section{Bibliography}

Booker, Christopher, The Neophiliacs. London, Collins, 1969.

Brooke, Rupert, The Old Vicarage, Grantchester. London, Sidgwick and Jackson, 1927.

Cartwright, F F, A Social History of Medicine. London, Longman, 1977.

Cole, G D, and Postgate, R, The Common People 1746-1946. London, Methuen, 1961.

DHSS, Annual Report 1976. London, HMSO, 1977.

Furth, C, Life Since 1900. London, Allen and Unwin, 1966.

Gibson, Sir Ronald, fournal of the Royal College of General Practitioners, $1968,15,3$.

Gibson, Sir Ronald, British Medical fournal, 1971, 2, 549.

Godber, Sir George, Fournal of the Royal College of General Practitioners, 1968, 16, 175.

Hunt, Arthur, The Quality of Life in Youth. RCN Conference, June 1975.

Jones, R B, Economic and Social History of England 1770-1970. London, Longman, 1971.

Klein, Rudolf, ed, Inflation and Priorities. London, Centre for Studies in Social Policy, 1975.

Marwick, Arthur, Britain in the Century of Total War. London, Bodley Head, 1968.

Orwell, G, The Road to Wigan Pier. London, Secker and Warburg, 1937.

Prest, A R, and Coppock, D J, eds, The UK Economy: A Manual of Applied Economics, 6th edn. London, Weidenfeld and Nicholson, 1974.

Priestley, J B, English fourney. London, Heinemann, 1934.

Sleeman, J F, The Welfare State. London, Allen and Unwin, 1973.

Stevenson, Joan, and Cook, Chris, The Slump. London, Jonathan Cape, 1977.

Thorn, John, A Personal View (The Trusty Servant). Wells, Winchester, 1978.

Tomlin, E W F, New University Quarterly, Summer 1978.

Trevelyan, G M, English Social History. London, Longman, 1946.

Wood, Anthony, Great Britain 1900-1965. London, Longman, 1978.

(Accepted 9 April 1979)
Are half-way houses in geriatric practice more suitable methods of discharge than return home?

The discharge of an old person from hospital depends on a balance being struck between the patient's capacity to survive outside hospital and the care available to him in the community. Only occasionally is the old person himself too apprehensive to ask for discharge. More often his relatives and friends express apprehension and perhaps try to prevent discharge. There is usually no problem about discharging someone who is continent, fully ambulant, mentally reliable, and able to dress and manage stairs. Problems arise when the patient's functional capacity falls short of these achievements.

It helps to prepare both patient and relatives psychologically for discharge by a period of treatment in a clearly identified predischarge place such as a half-way house. This can also be achieved in hospital by having a ward for predischarge patients, where the emphasis is on training for self-care in walking, managing in the lavatory, dressing, etc. A particularly important point is training to manage his own medication. Where a discharge is hazardous it is often worth while sending the patient home for a trial period of one or two days with the option to readmit if the discharge is unsuccessful. It is also extremely helpful to offer the patient and relations the extra security provided by attendance at a geriatric day hospital in the early weeks after discharge. A liaison health visitor who can keep in touch with the patient in the first few anxious days after return home is an additional safeguard. It is vital to ensure that all the community services on which the patient's support after discharge from hospital will depend are actually provided at the times expected. This calls for the skill of the social worker. 